\title{
Determinants of Delay in Diagnosis and Treatment in Multi Drug- Resistant Tuberculosis Patients in Health Facilities
}

\author{
Yusup Subagio Sutanto'), Paulus Wisnu Kuncoro Murti'), Reviono'), \\ Ari Natalia Probandari²), Hendra Kurniawan') \\ 1)Department of Pulmonology and Respiratory Medicine, Faculty of Medicine \\ Universitas Sebelas Maret/ Dr. Moewardi Hospital, Surakarta \\ ${ }^{2)}$ Department of Public Health, Faculty of Medicine, Universitas Sebelas Maret
}

\section{ABSTRACT}

Background: Multidrug-resistant tuberculosis (MDR-TB) is a serious threat to global TB control programs. According to WHO, there are 23,000 cases of TB multidrug-/rifampicinresistant (MDR/RR-TB) in Indonesia. In 2017, there were 442,000 of TB cases. There were 8,600 - 15,000 MDR/RR-TB cases, of which $2.4 \%$ were new cases and $13 \%$ were previously treated TB cases. This study aims to determine the factors that influence the delay in diagnosis and treatment of MDR-TB patients.

Subjects and Method: This study was a cross-sectional study conducted at Dr. Moewardi hospital, from September to October 2017, Surakarta, Central Java. A sample of 73 MDR-TB patients with disabilities on medical records was selected for this study. The dependent variables were delay in diagnosis and delay in therapy of MDR-TB cases. The independent variables were age, gender, distance to health facilities, and type of health facilities. Data were collected from medical records of MDR-TB patients who were treated from March 2012 to March 2017. Data were analyzed using the chi-square model.

Results: Median delay in diagnosis $=4$ days. Median treatment delay $=12$ days. The average patient who had delayed MDR-TB therapy ( $\geq 4$ days) was 44 years old (Mean $=44.19 ; \mathrm{SD}=$ 12.64). Delay in MDR-TB diagnosis was not significantly associated with gender $(\mathrm{OR}=0.53$; $95 \% \mathrm{CI}=0.18$ to $1.57 ; \mathrm{p}=0.264$ ), distance to health facility $(\mathrm{OR}=1.56 ; 95 \% \mathrm{CI}=0.58$ to 4.21 ; $\mathrm{p}=0.389$ ), and type of health facility (OR= $0.60 ; 95 \% \mathrm{CI}=0.26$ to $1.41 ; \mathrm{p}=0.983)$. The average of patient who had delayed MDR-TB therapy ( $\geq 12$ days) was 41 years old (Mean= 41.39; $\mathrm{SD}=12.69)$. Treatment delay was not significantly related to gender $(\mathrm{OR}=0.45 ; 95 \%$ $\mathrm{CI}=0.16$ to $1.26 ; \mathrm{p}=0.137)$, distance to health facility $(\mathrm{OR}=1.44 ; 95 \% \mathrm{CI}=0.55$ to $3.78 ; \mathrm{p}=$ $0.466)$, and type of health facility $(\mathrm{OR}=2.31$; $95 \% \mathrm{CI}=1.03$ to $5.21 ; \mathrm{p}=2.967)$.

Conclusion: There was no statistically significant relationship between gender, distance from the patient's home to health facilities, and type of health facility with the delay in diagnosis and treatment of MDR-TB patients.

Keywords: diagnosis, treatment, TB-MDR

\section{Correspondence:}

Yusup Subagio Sutanto. Department of Pulmonology and Respiratory Medicine, Faculty of Medicine Universitas Sebelas Maret/ Dr. Moewardi Hospital, Surakarta. Jl. Kolonel Sutarto No.132, Jebres, Surakarta, Central Java 57126. Email: dr_yusupsubagio@yahoo.com. Mobile: 0811284165 .

Cite this as:

Sutanto YS, Paulus Wisnu Kuncoro Murt, Reviono, Probandari AN, Kurniawan H (2021). Determinants of Delay in Diagnosis and Treatment in Multi Drug-Resistant Tuberculosis Patients in Health Facilities. Indones J Med. 06(01): 14-22. https://doi.org/10.26911/theijmed.2021.06.01.02.

cc (i) (2) Indonesian Journal of Medicine is licensed under a Creative Commons

EY NO SA Attribution-NonCommercial-ShareAlike 4.0 International License.

BACKGROUND

Indonesia is in the 12th rank among 27 countries that have a high burden for Anti-
Tuberculosis Drug-resistant Tuberculosis (OAT-resistant TB) or Multidrug Resistance Tuberculosis (TB-MDR). MDR-TB is a 
human-made phenomenon resulting from inadequate treatment and transmission from MDR-TB patients. Management of MDR-TB is more complicated and requires more attention than management of nonresistant TB. Management of MDR-TB is known as Integrated Management of DrugResistant Tuberculosis (MTPTRO) or Programmatic Management of Drug Resistant TB (PMDT). This guideline is recommended to become a guide for all MDR-TB program managers and health workers in health service facilities, both TB-MDR referral hospitals, Community Lung Health Centers (BBKPM), Community Lung Health Centers (BKPM), satellite puskesmas, and other related parties. MDR-TB is an important threat to global TB control and poses a huge burden to the international community because of its difficult, expensive, ineffective, and risky side effects handling (Ministry of Health, 2014; Zhang et al., 2015; WHO, 2016).

Approximately $75 \%$ of patients with pulmonary tuberculosis are in the economically productive age group, which is $15^{-}$ 50 years. It is estimated that an adult with pulmonary tuberculosis will lose an average of three to four months of working time. This results in an annual loss of household income of around $20-30 \%$. If they die from TB disease, it is estimated that they will lose their income for about 15 years. Apart from being economically detrimental, TB also has a negative impact socially and is sometimes isolated by the community. Losses due to pulmonary tuberculosis include health and socio-economic aspects. TB is considered a threat to development goals in improving people's welfare (Ministry of Health of the Republic of Indonesia, 2011; Zhang et al., 2015).

Delay in MDR-TB treatment could leave more patients affected and also hinder the efforts to prevent the spread of
MDR-TB. Delays in treatment result in poor treatment outcomes, further transmission, and incidence of MDR-TB. Delay in treatment and inadequate treatment with a single second line drug (SLD) also increases the risk of extensive drug resistance (XDR) (Ministry of Health of the Republic of Indonesia, 2014).

Delay in diagnosis will lead to the transmission of infection, increasing the risk of death, and worsening the economic situation of the patient and family. Delay in diagnosis is caused by patient delay and delays in health facilities (healthcare delay). The delay in TB diagnosis is influenced by age, residence, gender, level of education, access to health services, and the time the patient first consulted to a health service provider (Ministry of Health, 2014).

The low coverage of case finding in Indonesia indicates that there are still many delays in diagnosis. If patients can be found early and treated until they recover, the incidence rate of disease will be reduced, the chain of transmission can be broken, and TB disease will no longer be a health problem in Indonesia (Rifat et al., 2015).

Delay in diagnosis and treatment can lead to faster transmission of germs. Doctors and hospitals can provide information and education to health personnel at health centers to immediately refer positive cases of Acid Resistant Basil (BTA) to the hospital so that they can be given intensive Directly Observed Treatment Short-course (DOTS) treatment. Therefore, the spread can be prevented and healing can be accelerated (Ministry of Health, 2013; Rifat et al., 2015; Ministry of Health of the Republic of Indonesia, 2016). This study aims to determine the factors that influence the delay in diagnosis and treatment of MDR-TB patients. 


\section{SUBJECTS AND METHOD}

\section{Study Design}

This study was an observational study with a cross-sectional design conducted at Dr. Moewardi Hospital, Surakarta, Central Java, from March 2012 to March 2017.

\section{Population and Sample}

The source population of the study were MDR-TB patients who were referred and treated in March 2012 to March 2017 at Dr. Moewardi Hospital. The sample size in this study was 73 MDR-TB patients who were recorded in medical records.

\section{Study Variables}

The dependent variable was delay in diagnosis and treatment. The independent variables were age, gender, distance from the patient's house to health facilities, and type of referring health facilities.

\section{Definition of Operational Study}

Delay in diagnosis is the time interval between the occurrence of symptoms and a confirmed diagnosis of MDR-TB disease.

Delay in treatment is the time interval for diagnosis of MDR-TB to the date of definitive treatment for MDR-TB.

Age is the patient's age (in years old) when the study data were collected.

Gender is the biological and anatomical division of gender expressed in terms of male and female gender.

Distance to health facility is the distance from the patient's residence (in kilometers) to health facilities for the diagnosis and treatment of MDR-TB.

Type of health facility is a type of health facility before the patient was diagnosed with MDR-TB, namely primary services such as community health center, BBKPM, and BKPM and secondary services: hospitals.

MDR-TB suspect criteria is a person with TB symptoms (cough with phlegm $\geq 2$ weeks) and fulfills the following suspect criteria: (1) Criterion 1: the patient fails category-2 treatment; (2) Criterion 2: category-2 treatment patients did not convert after 3 months of treatment; (3) Criterion 3: the patient has a history of non-standard TB treatment and uses quinolones and second-line injection drugs for at least 1 month; (4) Criterion 4: patients fail category-1 treatment; (5) Criterion 5: patient category-1 treatment was not conversion; (6) Criterion 6: patient cases relapse after category-1 and category-2 OAT therapy; (7) Criteria 7: patients are negligent/defaulted (category 1 or category 2); (8) Criterion 8: TB patients who have a history of contact with MDR-TB patients; and (9) Criterion 9: TB-HIV co-infected patients did not respond clinically or bacteriologically to the administration of OAT.

\section{Study Instrument}

The study instruments were questionnaire and interviews with MDR-TB patients.

\section{Study Ethic}

This study has received approval of ethical feasibility from the health study ethics commission of Dr. Moewardi Hospital, Surakarta, Central Java with number 911/IX/HREC/2017.

\section{Data Analysis}

The relationship between the independent variable and the dependent variable was analyzed by chi-square using SPSS 21 .

\section{RESULTS}

\section{Sample Characteristic}

Of the 73 patients eligible for analysis were 50 men (68.49\%) and 23 women (31.50\%). Table 1 shows the mean patient age, which was 41.71 years old $(\mathrm{SD}=13.69)$. The mean distance from the patient's house (in kilometers) to health facilities was $19.36 \mathrm{~km}$ $(\mathrm{SD}=21.03)$. Table 2 shows the types of health facilities that referred MDR-TB patients, namely 47 primary health facilities (64.36\%) and 26 hospitals (35.61\%). There were criteria for TB-MDR suspects with the 
Sutanto et al./ Determinants of Delay in Diagnosis and Treatment in Multi Drug-Resistant TB

highest order are criteria 4 by $21(28.76 \%)$, criteria 6 by 20 (27.39\%), criteria 5 by 11 (15.06\%), criteria 1 by 10 (13.69\%), criteria

Table 1. Sample Characteristic (continous data)

\begin{tabular}{lcccc}
\hline \multicolumn{1}{c}{ Variable } & Mean & SD & Min. & Max. \\
\hline Patients' age (years old) & 41.71 & 13.69 & 18 & 74 \\
Distance (km) & 19.36 & 21.03 & 0.3 & 8 \\
\hline
\end{tabular}

Table 2. Sample Characteristic (categorical data)

\begin{tabular}{llcc}
\hline \multicolumn{1}{c}{ Characteristic } & Category & Frequency & Percentage \\
\hline \multirow{2}{*}{ Gender } & Female & 23 & $31.50 \%$ \\
Type of Health Facility & Male & 50 & $68.49 \%$ \\
& Primary & 47 & $64.36 \%$ \\
& Hospital & 26 & $35.61 \%$ \\
& Criteria 1 & 10 & $13.69 \%$ \\
& Criteria 2 & 3 & $4.10 \%$ \\
TB-MDR Suspect Criteria & Criteria 3 & 0 & $0 \%$ \\
& Criteria 4 & 21 & $28.76 \%$ \\
& Criteria 5 & 11 & $15.06 \%$ \\
& Criteria 6 & 20 & $27.39 \%$ \\
& Criteria 7 & 8 & $10.95 \%$ \\
& Criteria 8 & 0 & $0 \%$ \\
\hline
\end{tabular}

2. Result of Bivariate Analysis

Table 3. Association of age (years old) with delay in diagnosis (defined $\geq 4$ days) in MDR-TB patients

\begin{tabular}{lcccc}
\hline Time of Diagnosis (Days) & n & Mean & SD & p \\
\hline$<4$ & 47 & 40.00 & 14.18 & \multirow{2}{*}{0.252} \\
$\geq 4$ & 26 & 44.19 & 12.64 & \\
\hline
\end{tabular}

Table 3 shows the mean of patients who experienced late diagnosis of MDR-TB $(\geq 4$ days) aged 44 years old (Mean= 44.19; $\mathrm{SD}=12.64)$.

Table 4. Association of late diagnosis (defined $\geq 4$ days) with socio-demographic factors and clinical characteristics in MDR-TB patients

\begin{tabular}{|c|c|c|c|c|c|c|c|c|c|}
\hline \multirow{3}{*}{ Variable } & & \multicolumn{4}{|c|}{$\begin{array}{c}\text { Time of Diagnosis } \\
\text { (Days) }\end{array}$} & \multirow{3}{*}{$\mathbf{O R}$} & \multirow{2}{*}{\multicolumn{2}{|c|}{ 95\% CI }} & \multirow{3}{*}{$\mathbf{p}$} \\
\hline & & \multicolumn{2}{|c|}{$<4$} & \multicolumn{2}{|r|}{$\geq 4$} & & & & \\
\hline & & $\mathbf{N}$ & $\%$ & $\mathbf{N}$ & $\%$ & & $\begin{array}{l}\text { Lower } \\
\text { Limit }\end{array}$ & $\begin{array}{l}\text { Upper } \\
\text { Limit }\end{array}$ & \\
\hline Gender & $\begin{array}{l}\text { Male } \\
\text { Female }\end{array}$ & $\begin{array}{l}30 \\
17\end{array}$ & $\begin{array}{l}60.00 \\
73.91\end{array}$ & $\begin{array}{c}20 \\
6\end{array}$ & $\begin{array}{l}40.00 \\
26.09\end{array}$ & 0.53 & 0.18 & 1.57 & 0.264 \\
\hline Distance to & $<19$ & 32 & 68.09 & 15 & 31.91 & & & & \\
\hline $\begin{array}{l}\text { health facility } \\
(\mathrm{km})\end{array}$ & $\geq 19$ & 15 & 57.69 & 11 & 42.30 & 1.56 & 0.58 & 4.21 & 0.389 \\
\hline $\begin{array}{l}\text { Type of health } \\
\text { facility }\end{array}$ & $\begin{array}{l}\text { Primary } \\
\text { Hospital }\end{array}$ & $\begin{array}{l}27 \\
20\end{array}$ & $\begin{array}{l}60.00 \\
71.42\end{array}$ & $\begin{array}{c}18 \\
8\end{array}$ & $\begin{array}{l}40.00 \\
28.57\end{array}$ & 0.6 & 0.256 & 1.405 & 0.983 \\
\hline
\end{tabular}


Table 4 shows the relationship between diagnosis delay (defined $\geq 4$ days) and socio-demographic factors and clinical characteristics in MDR-TB patients. In the study, the average time of diagnosis (in days) was 7.58 and the median was 4 . According to gender, there were 30 (60\%) male patients and 17 (73.91\%) female patients who were not experienced late diagnosis. The distance from the patient's residence to the health facility $<19 \mathrm{~km}$ in the group with no late diagnosis was 32 (68.09\%) patients. A distance of $\geq 19 \mathrm{~km}$ in the non-late diagnosis group was 15 (57.69\%) patients. Patients from the type of primary health care facility with no late diagnosis were 27 (60\%) patients. The majority of patients who had no late diagnosis from hospital services were 20 (71.42\%) patients. Factors which were not significantly associated with late diagnosis were gender $(\mathrm{OR}=0.53 ; 95 \% \mathrm{CI}=0.18$ to $1.57 ; \mathrm{p}=0.264)$, distance to health facility $(\mathrm{OR}=1.56 ; 95 \% \mathrm{CI}=0.58$ to $4.21 ; \mathrm{p}=$ $0.389)$, and type of health facility $(\mathrm{OR}=$ $0.60 ; 95 \% \mathrm{CI}=0.26$ to $1.41 ; \mathrm{p}=0.983)$.

Table 5. Association of age (years) and delay in therapy (defined $\geq 12$ days) in MDR-TB patients

\begin{tabular}{lcccc}
\hline Therapy Time (Days) & n & Mean & SD & p \\
\hline$<12$ & 38 & 42.06 & 14.87 & \multirow{2}{*}{0.838} \\
$\geq 12$ & 35 & 41.39 & 12.69 & \\
\hline
\end{tabular}

Table 5 shows the average of patients who experienced delays in MDR-TB therapy ( $\geq 12$ days) aged 41 years old Table 6. Association of delay in therapy (defined $\geq 12$ days) with socio-demographic factors and clinical characteristics in MDR-TB patients

\begin{tabular}{|c|c|c|c|c|c|c|c|c|c|}
\hline \multirow{3}{*}{ Variable } & & \multicolumn{4}{|c|}{ Therapy Time (Days) } & \multirow{3}{*}{$\mathbf{O R}$} & \multirow{2}{*}{\multicolumn{2}{|c|}{$95 \%$ CI }} & \multirow{3}{*}{$\mathbf{p}$} \\
\hline & & \multicolumn{2}{|c|}{$<12$} & \multicolumn{2}{|c|}{$\geq 12$} & & & & \\
\hline & & $\mathbf{N}$ & $\%$ & $\mathbf{N}$ & $\%$ & & $\begin{array}{c}\text { Lower } \\
\text { Limit }\end{array}$ & $\begin{array}{l}\text { Upper } \\
\text { Limit }\end{array}$ & \\
\hline Gender & $\begin{array}{l}\text { Male } \\
\text { Female }\end{array}$ & 23 & 46 & $\begin{array}{l}27 \\
8\end{array}$ & 54 & 0.45 & 0.16 & 1.26 & 0.137 \\
\hline Distance to & serlo & $\begin{array}{c}15 \\
2\end{array}$ & 05.22 & & $34 . / 0$ & & & & \\
\hline health facility & $<19$ & 6 & $55 \cdot 32$ & 21 & 44.68 & 1.44 & 0.55 & 3.78 & 0.466 \\
\hline$(\mathbf{k m})$ & $\geq 19$ & 12 & 46.15 & 14 & 53.85 & & & & \\
\hline Type of health & Primary & 27 & 60.00 & 18 & 40.00 & 2.31 & 1.03 & 5.21 & 2.967 \\
\hline facility & Hospital & 11 & 39.28 & 17 & 60.71 & 2.31 & 1000 & 5.2 & \\
\hline
\end{tabular}

Table 6 shows the relationship between delay in therapy with socio-demographic factors and clinical characteristics in patients. There were 50 men consisting of $23(46 \%)$ patients who did not delay the treatment. The distance between the patient's residence and the health facility $<19$ $\mathrm{km}$ in the group that did not delay treatment was 26 (55.30\%). A distance of $\geq 19$ $\mathrm{km}$ in the treatment delay group was 15 (65.20\%) patients. Patients from the pri- mary health facility type who did not delay therapy were 27 (60\%) patients. The majority of delays in therapy from hospital services were 17 (60.71\%) patients. Treatment delay was not significantly related to gender $(\mathrm{OR}=0.45 ; 95 \% \mathrm{CI}=0.16$ to $1.26 ; \mathrm{p}=0.137)$, distance to health facility $(\mathrm{OR}=1.44 ; 95 \%$ $\mathrm{CI}=0.55$ to $3.78 ; \mathrm{p}=0.466$ ), and type of health facility $(\mathrm{OR}=2.31 ; 95 \% \mathrm{CI}=1.03$ to $5.21 ; \mathrm{p}=2.967)$. 


\section{DISCUSSION}

This study measured the factors that influence the delay in diagnosis and treatment in MDR-TB patients at Dr. Moewardi Hospital, Surakarta. The average patient with late diagnosis of MDR-TB was 44 years old. Some of the results of previous studies showed that there was no statistically significant relationship between age and delay in diagnosis (Lusignani et al., 2013; Osei et al., 2015; Said et al., 2017).

This study found that patients' gender was not statistically significant with late diagnosis. The results obtained that the late diagnosis is more in male than female. This can be because men are more often out of the house because of their work. Women have more time to consult at health facilities for complaints of their illness. This study was similar to a study conducted in Tanzania by Said et al. (2017) which found more late diagnosis in men (68\%) than in women (34\%).

In this study, the distance between MDR-TB patients' residences and health care facilities of $\geq 19 \mathrm{~km}$ was associated with delay in diagnosis and therapy. In this study, 26 patients lived with a distance of $\geq 19 \mathrm{~km}$ from health facilities. This study indicated that a distance of $\geq 19 \mathrm{~km}$ was a risk factor for late diagnosis of MDR-TB, but it was not statistically significant. This is supported by the research of Bekana et al. (2017) in Ethiopia with a 21-day intersection, stated that residence $\geq 10 \mathrm{~km}$ away had more delay in diagnosis than residence $<10 \mathrm{~km}$ away (Farazi and Jabbariasl, 2012; Konda et al., 2014).

This study found that patients who experienced delay in diagnosis were found from primary care in 18 (40\%) patients. This delay in diagnosis may occur because the clinical symptoms of the patients are not specific to the diagnosis of TB so that the patients do not have sputum checked as soon as possible. The referral system that requires several patients to go to the puskesmas first before going to the hospital can also affect the speed of diagnosis. Patients with clinical atypical, sputum examinations that are not promptly, and tiered referral make the patient's journey longer to undergo the TB and MDR-TB diagnostic process. Previous studies found no significant effect of different types of health facilities in diagnosing TB and MDR-TB (Alavi et al., 2015; Bekana et al., 2017).

A study by Nyatichi and Amimo (2016) in Kenya comparing hospital health facilities, private clinics, health centers, and herbal practices found wrong patient perceptions about the type of service provided in each health facility, which affects the delay in diagnosis. The results of the study in Ethiopia stated that the delay in TB diagnosis occurred due to differences in the types of facilities only in hospitals for sputum examination with molecular rapid tests and chest X-rays (Adenager et al., 2017).

This study found 21 patients with the most MDR-TB suspicion criteria for category-1 treatment failure criteria. There were 20 patients with cases of relapse after category-1 and category-2 OAT therapy. Other criteria obtained in this study were 11 patients who did not convert category-1 treatment, 10 patients who failed category-2 treatment, 8 patients who neglected treatment (category 1 or category 2), and 3 patients who did not treat category-2 treatment, conversion after 3 months of treatment. Research by Rifat et al (2015) stated that prolonged therapy can cause patients to take longer to make a diagnosis of MDRTB. However, this study did not seek a relationship between MDR-TB suspect criteria with late diagnosis and therapy.

This study found that an average patient who had delayed MDR-TB therapy 
was 41 years old. Research by Zhang et al. (2015) in China with a sample size of 110 patients and a median delay of treatment of 9 days found no statistically significant effect of age on treatment delay.

The results of this study indicated the delay in treatment is more in men than women. A study with similar results was found in Tanzania by Said et al. (2017) which stated that more men $(68 \%)$ had late diagnosis than women (34\%). Another similar result was found in the study of Zhang et al. (2015) on MDR-TB patients in China. Age factor does not have a statistically significant effect on treatment delay (Zhang et al., 2015; Nyatichi and Amimo, 2016).

This study revealed no relationship between distance to health facilities and delay in treatment. The results of the study found that primary health services and hospitals already have a care system that follows procedures. There was no difference between the two levels of health facilities. This study found that patients who delayed treatment were from the primary care group. The examination process at Community Health Center and other primary services did not require a referral letter so that the patient was immediately treated by a doctor. Different research results from Nyatichi and Amimo (2016) in Kenya reported that from a sample of 133 patients, hospital health facilities, community health centers, and private clinics has $\mathrm{p}$ values $<0.001, \mathrm{p}=0.001$, and $\mathrm{p}<0.001$ where the patient is late for treatment due to a private clinic first. The delay limit is set at 30 days (Nyatichi and Amimo, 2016).

This study found that the number of patients who delayed treatment from the criteria for treatment failure was 17 (48.60\%), no conversion was 6 (17.10\%), and failed was $12(34.30 \%)$. These results are consistent with the research of Rifat et al. (2015) in Bangladesh which stated that of the previous treatment variables, the criterion for treatment failure had a maximum of $58.90 \%$ compared to other criteria regarding delay in health facilities. The study of Rifat et al. (2015) included delay in diagnosis and treatment, and it is not statistically significant $(\mathrm{p}=0.140$ and $\mathrm{p}=$ 0.080). It is possibly because of the failure criteria, the patient had for a long period of time that both failed the first or second treatment category.

There was no statistically significant relationship between gender, distance to health facilities, type of health facility, and presumed MDR-TB criteria for late diagnosis and treatment of MDR-TB patients.

\section{AUTHOR CONTRIBUTION}

Authors contributed to the concept, design, analysis, and discussion of data.

\section{CONFLICT OF INTEREST}

This study was self-funded.

\section{FUNDING AND SPONSORSHIP}

There was no conflict of interest in this study.

\section{ACKNOWLEDGEMENT}

We would like to show our gratitude to the Department of Pulmonology and Respiration Medicine, Faculty of Medicine, Sebelas Maret University for their support in this research.

\section{REFERENCE}

Adenager GS, Alemseged F, Asefa H, Gebremedhin AT (2017). Factors associated with treatment delay among pulmonary tuberculosis patients in public and private health facilities in Addis Ababa, Ethiopia. Tuberc Res Treat. 1-9. doi: 10.1155/2017/5120841. 
Sutanto et al./ Determinants of Delay in Diagnosis and Treatment in Multi Drug-Resistant TB

Alavi SM, Bakhtiyariniya P, Albagi A (2015). Factors associated with delay in diagnosis and treatment of pulmonary tuberculosis. Jundishapur $\mathrm{J}$ Microbiol. 8(3): 8-11. doi: 10.5812/jjm.19238.

Bekana W, Sisay M, Baye Y (2017). Evaluation of factors affecting patient delay in the diagnosis and treatment of $t b$ among tb patients attending in Hiwot Fana specialized University Hospital, Harar, Eastern Ethiopia. J Infect Dis Preve Med. 05(01): 1-7. doi: 10.4172/2329-8731.1000149.

Farazi A, Jabbariasl M (2012). Time delay and associated factors in diagnosis and treatment of pulmonary tuberculosis in Markazi Province. J Health Res. 1(1): 46-53.

Kemenkes RI (2013). Pedoman Nasional Pelayanan Kedokteran Tata Laksana Tuberkulosis (National Guidelines for Tuberculosis Medical Service Administration). Jakarta: Kementerian Kesehatan Republik Indonesia.

Kemenkes RI (2011). Pedoman nasional pengendalian tuberkulosis-keputusan Menteri Kesehatan Republik Indonesia (National guidelines for tuberculosis control-decree of the Minister of Health of the Republic of Indonesia). Jakarta: Kementerian Kesehatan Republik Indonesia.

Kemenkes RI (2014). Petunjuk teknis manajemen terpadu pengendalian resistan obat (Technical guidelines for integrated management of drug resistance management). Jakarta: Kementerian Kesehatan Republik Indonesia.

Konda S, Melo C, Giri P, Behera A (2014). Determinants of delays in diagnosis and treatment of pulmonary tuberculosis in a new urban township in India: A cross-sectional study. Int $\mathrm{J}$ Med Sci Public Health. 3(2): 140. doi: 10.5455/ijmsph.2013.011120131.

Menteri Kesehatan Republik Indonesia (2014). Pedoman Nasional Tuberkulosis (National Tuberculosis Guidelines). Jakarta: Kementerian Kesehatan Republik Indonesia.

Nyatichi FO, Amimo FA (2016). Factors contributing to delay in seeking treatment among pulmonary tuberculosis patients in Suneka Sub-County, Kenya. J Health Educ. Res. Dev. 4(2). doi: 10.4172/2380-5439.1000170.

Osei E, Akweongo P, Binka F (2015). Factors associated with delay in diagnosis among tuberculosis patients in Hohoe Municipality, Ghana. BMC Public Health. 15(1): 1-11. doi: 10.1186/s12889-015-1922-z.

Rifat M, Hall J, Oldmeadow C, Husain A, Milton AH (2015). Health system delay in treatment of multidrug resistant tuberculosis patients in Bangladesh. BMC Infect Dis, 15(1): 1-8. doi: 10.1186/s12879-015-1253-9.

Said K, Hella J, Mhalu G, Chiryankubi M, Masika E, Maroa T, Mhimbira F, et al. (2017). Diagnostic delay and associated factors among patients with pulmonary tuberculosis in Dar es Salaam, Tanzania. Infect Dis Poverty. 6(1): 1-10. doi: 10.1186/s40249-0170276-4.

Lusignani LS, Quaglio G, Atzori A, Nsuka J, Grianger R, Palma MDC, Putoto G, et al. (2013). Factors associated with patient and health care system delay in diagnosis for tuberculosis in the province of Luanda, Angola. BMC Infect Dis. 13(1). doi: 10.1186/14712334-13-168.

WHO (2016). WHO treatment guidelines for drug-resistant tuberculosis. Geneva: WHO Document Production Services.

Zhang X, Yin J, Li H, Li S, Walley J, Zou G, 
Last name first author et al. (jikalebihdari 1)/ Sebagianjudul

Zhang Z, et al. (2015). Diagnostic and treatment delays of multidrug-resistant tuberculosis before initiating treatment: a cross-sectional study. Trop Med Int Health. 20(11): 14311437. doi: 10.1111/tmi.12566. 